\title{
PENGARUH MANAJEMEN ASET DAN STRUKTUR MODAL TERHADAP PROFITABILITAS PADA PERUSAHAAN SUB SEKTOR KERAMIK, PORSELEN DAN KACA YANG TERDAFTAR DI BURSA EFEK INDONESIA
}

\author{
Oleh : \\ Eliza Arshandy \\ S1 Akuntansi
}

Abstrak

Tujuan dari penelitian ini adalah untuk mengetahui gambaran manajemen aset, struktur modal, dan profitabilitas serta pengaruh manajemen aset dan struktur modal terhadap profitabilitas pada Perusahaan Sub Sektor Keramik, Porselen dan Kaca yang terdaftar di Bursa Efek Indonesia. Desain penelitian yang digunakan adalah penelitian kepustakaan. Teknik analisis data yang digunakan adalah: uji asumsi klasik, analisis deskriptif kualitatif dan kuantitatif.

Hasil penelitian ini adalah $\hat{Y}=-0,044+0,072 X_{1}+0,013 X_{2}$. Koefisien korelasi sebesar 0,788 dan nilai $R$ Square sebesar 0,622 . Hasil uji $F$ menunjukkan bahwa $F_{\text {hitung }}>F_{\text {tabel }}(18,079>3,44)$ atau tingkat signifikansi $0,000<0,05$ berarti manajemen aset dan struktur modal berpengaruh signifikan terhadap profitabilitas pada Perusahaan Sub Sektor Keramik, Porselen dan Kaca yang terdaftar di Bursa Efek Indonesia. Hasil uji $t$ untuk manajemen aset $t_{\text {hitung }}>t_{\text {tabel }}(4,911>2,073)$ atau Sig. $>$ alpha $(0,000<0,05)$, berarti manajemen aset berpengaruh signifikan terhadap profitabilitas pada Perusahaan Sub Sektor Keramik, Porselen dan Kaca yang terdaftar di Bursa Efek Indonesia. Hasil uji t untuk struktur modal $\mathrm{t}_{\text {hitung }}<\mathrm{t}_{\text {tabel }}(-1,421<2,073)$ atau Sig.>alpha $(0,169>0,05)$, berarti struktur modal berpengaruh tidak signifikan terhadap profitabilitas pada Perusahaan Sub Sektor Keramik, Porselen dan Kaca yang terdaftar di Bursa Efek Indonesia.

Saran yang dapat diberikan adalah perusahaan sebaiknya tidak menambah terlalu banyak aset apabila aset tersebut tidak mendukung peningkatan penjualan, dan mengoptimalkan penggunaan utang serta mencari kreditur dengan tingkat suku bunga yang lebih rendah.

Kata Kunci: manajemen aset, struktur modal dan profitabilitas

\section{Abstract}

The purpose of this research is to know the description of asset management, capital structure and profitability and the influence of asset management and capital structure on profitability at Firm in Sub-Sector Keramik, Porselen dan Kaca listed on the Indonesia Stock Exchange. The research design is a library research. The analysis data technique is: assumption classic test, qualitative and quantitative descriptive analysis

The result is $\hat{Y}=-0,044+0,072 X_{1}+0,013 X_{2}$. Correlation coefficient $=0,788$ and $R$ Square 0,622 . Simultaneous test results obtained $F_{\text {count }}>F_{\text {table }}(18,079>3,44)$ or significance level obtained $0,000<0,05$ means management and capital structure has significant effect on profitability at Firm in Sub-Sector Keramik, Porselen dan Kaca listed on the Indonesian Stock Exchange. The t-test for asset management shown $t_{\text {count }}>t_{\text {table }}(4,911>2,073)$ or significance level is $0,000<0,05$ means asset management has insignificant effect on the profitability at Firm in Sub-Sector Keramik, Porselen dan Kaca listed on the Indonesian Stock Exchange. The t-test for capital structure shown $t_{\text {count }}<t_{\text {table }}$ ($1,421<2,073$ ) or significance level is $0,169>0,05$ means capital structure has insignificant effect on profitability at Firm in Sub-Sector Keramik, Porselen dan Kaca listed on the Indonesian Stock Exchange.

The result of this research suggests the Company should not adding to much assets if that not increased in sales and also optimize the use of debt and the company seeks credition with lower interest rate.

Keywords: management, capital structure and profitability

\section{A. PENDAHULUAN}

\section{Latar Belakang Masalah}

Sebuah perusahaan atau lembaga usaha baik milik pemerintah maupun swasta dituntut untuk lebih memaksimalkan kinerjanya dalam berbagai hal, terutama dalam hal memperoleh laba. Profitabilitas dengan dimensi Return On Assets (ROA) menunjukkan kemampuan perusahaan untuk menghasilkan laba dengan menggunakan aset yang ada di dalam perusahaan tersebut.

Terdapat beberapa faktor yang mempengaruhi profitabilitas suatu perusahaan seperti manajemen aset. Manajemen aset merupakan rasio yang mengukur kemampuan perusahaan dalam mengelola asetnya. Faktor lain yang mempengaruhi profitabilitas suatu perusahaan adalah struktur modal. Struktur 
modal adalah suatu struktur yang menggambarkan hutang jangka panjang dan modal sendiri dalam suatu perusahaan.

$$
\text { Tabel } 1
$$

Gambaran ROA Perusahaan Sub Sektor Keramik, Porselen dan Kaca Periode 20122016

\begin{tabular}{|c|c|c|c|c|c|c|}
\hline $\begin{array}{c}\text { Kode } \\
\text { Emiten }\end{array}$ & $\begin{array}{c}\text { Tahun } \\
\mathbf{2 0 1 2} \\
\text { (kali) }\end{array}$ & $\begin{array}{c}\text { Tahun } \\
\mathbf{2 0 1 3} \\
\text { (kali) }\end{array}$ & $\begin{array}{c}\text { Tahun } \\
\mathbf{2 0 1 4} \\
\text { (kali) }\end{array}$ & $\begin{array}{c}\text { Tahun } \\
\mathbf{2 0 1 5} \\
\text { (kali) }\end{array}$ & $\begin{array}{c}\text { Tahun } \\
\mathbf{2 0 1 6} \\
\text { (kali) }\end{array}$ & $\begin{array}{c}\text { Rata- } \\
\text { rata } \\
\text { ROA } \\
\text { (kali) }\end{array}$ \\
\hline AMFG & 0,11 & 0,10 & 0,12 & 0,08 & 0,05 & $\mathbf{0 , 0 9 2}$ \\
\hline ARNA & 0,17 & 0,21 & 0,21 & 0,05 & 0,06 & $\mathbf{0 , 1 4}$ \\
\hline KIAS & 0,03 & 0,03 & 0,04 & $-0,08$ & $-0,14$ & - \\
& 0,024 \\
\hline MLIA & 0,00 & $-0,07$ & 0,02 & $-0,02$ & 0,00 & - \\
\hline TOTO & 0,15 & 0,14 & 0,14 & 0,12 & 0,07 & $\mathbf{0 , 1 2 4}$ \\
\hline $\begin{array}{c}\text { Rata- } \\
\text { Rata }\end{array}$ & $\mathbf{0 , 0 9}$ & $\mathbf{0 , 0 8}$ & $\mathbf{0 , 1 1}$ & $\mathbf{0 , 0 3}$ & $\mathbf{0 , 0 1}$ & $\mathbf{0 , 0 6 4}$ \\
\hline
\end{tabular}

Dari Tabel 1 dapat dilihat rata-rata per tahun ROA Perusahaan Sub Sektor Keramik, Porselen dan Kaca yang terdaftar di Bursa Efek Indonesia periode 2012-2016 mengalami fluktuasi dan cenderung menurun. Rata-rata ROA Perusahaan Sub Sektor Keramik, Porselen dan Kaca selama periode penelitian sebesar 0,064 artinya setiap Rp. 1 Aset dapat menghasilkan laba setelah pajak sebesar Rp. 0,064

\section{Rumusan Masalah}

a. Bagaimana gambaran manajemen aset,, struktur modal dan profitabilitas pada Perusahaan Sub Sektor Keramik, Porselen dan Kaca yang terdaftar di Bursa Efek Indonesia.

b. Bagaimana pengaruh manajemen aset dan struktur modal terhadap profitabilitas pada Perusahaan Sub Sektor Keramik, Porselen dan Kaca yang terdaftar di Bursa Efek Indonesia baik secara simultan maupun parsial.

\section{Tujuan Penelitian}

a. Untuk mengetahui gambaran umum manajemen aset, struktur modal dan profitabilitas pada Perusahaan Sub Sektor Keramik, Porselen dan Kaca yang terdaftar di Bursa Efek Indonesia.

b. Untuk mengetahui pengaruh manajemen aset dan struktur modal terhadap profitabilitas pada Perusahaan Sub Sektor Keramik, Porselen dan Kaca yang terdaftar di Bursa Efek Indonesia baik secara simultan maupun parsial.

\section{Metodologi Penelitian}

Penelitian ini menggunakan data sekunder, dilakukan dengan cara mengakses dari situs http://www.idx.co.id. Desain penelitian yang digunakan adalah penelitian kepustakaan (library research). Teknik analisa data dalam penelitian ini adalah Uji Asumsi Klasik, Analisa
Deskriptif Kualitatif, Analisa Deskriptif Kuantitatif.

\section{B. LANDASAN TEOR}

\section{Laporan Keuangan}

Menurut Martani, dkk (2012:8), laporan keuangan adalah informasi keuangan yang dihasilkan oleh proses akuntansi.

Menurut Baridwan (2004:17), laporan keuangan adalah ringkasan dari suatu proses pencatatan dari transaksi-transaksi keuangan yang terjadi selama tahun buku yang bersangkutan.

Menurut Hery (2009:6), tujuan penyajian laporan oleh suatu entitas dapat dirincikan sebagai berikut:

a. Menginformasikan hal-hal terpercaya tentang sumber daya ekonomi dan kewajiban perusahaan.

b. Menginformasikan hal-hal terpercaya tentang sumber kekayaan bersih yang berasal dari kegiatan usaha dalam mencari laba.

c. Memungkinkan untuk menaksir potensi perusahaan dalam menghasilkan laba.

d. Mengungkapkan informasi relevan lainnya yang dibutuhkan para pemakai laporan.

\section{Analisis Rasio Keuangan}

Menurut Kasmir (2010:66), Analisis laporan keuangan merupakan salah satu indikator mengetahui kinerja perusahaan dalam suatu periode.

Menurut Horne dan John (2012:163), rasio keuangan merupakan indeks yang menghubungkan dua buah data keuangan dan diperoleh dengan membagi satu angka dengan angka lainnya.

\section{Manajemen Aset}

Menurut Atmaja (2003:415), Efficiency atau Turnover atau Asset Management Ratios, mengukur seberapa efektif perusahaan dalam mengelola aktivanya. Sedangkan menurut Astuti (2004:32), rasio manajemen aset mengukur efektivitas perusahaan dalam mengelola aktivanya, yaitu mengukur kemampuan seluruh aktiva dalam menghasilkan penjualan. Dalam penelitian ini menggunakan Fixed assets turnover ratio yang mengukur efisiensi dan efektivitas perusahaan dalam mengelola total aset tetapnya untuk menghasilkan penjualan.

\section{Struktur Modal}

Menurut Sudana (2011:143), struktur modal adalah pembelanjaan jangka panjang suatu perusahaan yang diukur dengan perbandingan utang jangka panjang dengan modal sendiri.

Menurut Sjahrial (2009:125), struktur modal merupakan perimbangan antara penggunaan modal pinjaman yang terdiri dari 
utang jangka pendek yang bersifat permanen, utang jangka panjang dengan modal sendiri yang terdiri dari saham preferen dan saham biasa.

Menurut Sudana (2011:153), struktur modal (capital structure) adalah pembelanjaan jangka panjang suatu perusahaan yang diukur dengan perbandingan utang jangka panjang dengan modal sendiri. Maka rasio untuk mengukur struktur modal adalah Long-term Debt to Equity Ratio (LtDER).

\section{Profitabilitas}

Rasio profitabilitas (profitability ratio) menurut Sudana (2011:22) adalah rasio yang mengukur kemampuan perusahaan untuk menghasilkan laba dengan menggunakan sumber-sumber yang dimiliki perusahaan, seperti aset, modal atau penjualan.

$$
\text { Return On Asset (ROA) }
$$

menggambarkan tingkat kemampuan perusahaan dengan menggunakan seluruh aset yang dimiliki untuk menghasilkan laba setelah pajak. Rasio ini penting bagi pihak manajemen untuk mengevaluasi efektivitas dan efisiensi perusahaan dalam mengolah seluruh aset perusahaan. Semakin besar ROA semakin efisien penggunaan aset perusahaan atau dengan kata lain dengan jumlah aset yang sama bisa dihasilkan laba yang lebih besar dan sebaliknya.

\section{Pengaruh Manajemen Aset dan} Struktur Modal terhadap Profitabilitas Menurut Sudana (2011:22), rasio perputaran aset tetap mengukur efektivitas penggunaaan aset tetap dalam menghasilkan penjualan bagi perusahaan. Semakin tinggi rasio ini maka semakin efektif pengelolaan aset tetap yang dilakukan oleh manajemen perusahaan. Dengan demikian sangat dimungkinkan bahwa hubungan antara Fixed Assets Turnover Ratio (FATO) dan Return On Assets (ROA) adalah positif. Semakin besar FATO akan semakin baik karena semakin efisien aset tetap yang digunakan untuk meningkatkan kegiatan penjualan.
Menuru
Sudana
(2011:153), berdasarkan Signaling Theory (teori sinyal), perusahaan yang mampu menghasilkan laba cenderung meningkatkan jumlah hutangnya, karena tambahan pembayaran bunga akan dimbangi dengan laba sebelum pajak. Semakin sukses suatu perusahaan, kemungkinan akan menggunakan lebih banyak utang. Jadi dapat disimpulkan semakin tinggi rasio hutang, maka semakin tinggi risiko keuangannya dimana risiko keuangan mempunyai hubungan positif dengan tingkat pengembalian sehingga jika semakin tinggi rasio ini, maka semakin besar tingkat pengembalian dan sebaliknya.

\section{PEMBAHASAN}

1. Analisis

a. Analisis Deskripsi Kualitatif

1) Gambaran Manajemen Aset

Rata-rata Fixed Assets Turnover (FATO) sebagai berikut:

Tabel 2

FATO pada Perusahaan Keramik, Porselen dan Kaca yang terdaftar di Bursa Efek Indonesia Periode 2012-2016

\begin{tabular}{|c|c|c|c|c|c|c|c|}
\hline No & $\begin{array}{c}\text { kode } \\
\text { emiten }\end{array}$ & 2012 & 2013 & 2014 & 2015 & 2016 & $\begin{array}{c}\text { Rata-Rata } \\
\text { Perusahaaan } \\
\text { (kali) }\end{array}$ \\
\hline 1 & AMFG & 2,06 & 2,18 & 2,4 & 2,01 & 1,06 & $\begin{array}{r}1,94 \\
\end{array}$ \\
\hline 2 & & 1,86 & 2,01 & 2,19 & 1,46 & 1,76 & 1,86 \\
\hline 3 & & 0,59 & 0,62 & 0,6 & 0,57 & 0,65 & 0,61 \\
\hline 4 & & 0,90 & 0,94 & 1,02 & 1,04 & 0,96 & 0,97 \\
\hline 5 & TOTO & 3,42 & 3,06 & 2,54 & 2,6 & 2,35 & 2,79 \\
\hline \multicolumn{2}{|c|}{$\begin{array}{l}\text { Rata-Rata Per } \\
\text { Tahun (kali) }\end{array}$} & & & & 1,54 & & \\
\hline \multicolumn{7}{|c|}{$\begin{array}{lll}1, I / & 1,6 \\
\text { FATO Minimum }\end{array}$} & $\frac{0,05}{0,57}$ \\
\hline \multicolumn{7}{|c|}{$\begin{array}{l}\text { FATO Maksimum } \\
\text { Rata-Rata FATO }\end{array}$} & $\frac{3,42}{1,63}$ \\
\hline
\end{tabular}

Sumber: Data diolah

Dari Tabel 2, dapat disajikan grafik sebagai berikut:

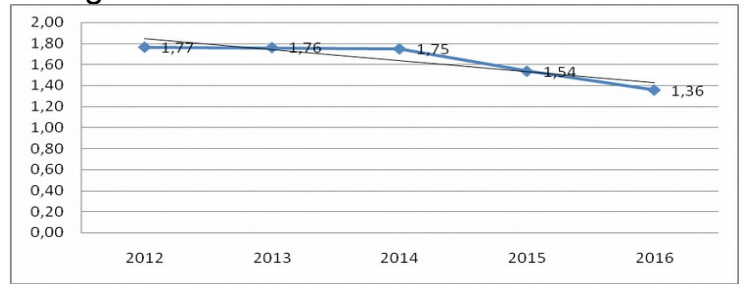

Sumber: Data Diolah (www.idx.co.id)

\section{Gambar 1}

Perkembangan FATO Perusahaan Keramik

Porselen dan Kaca periode 2012-2016

Berdasarkan Tabel 2 dan Gambar 1 menunjukkan FATO mengalami fluktuasi dan cenderung menurun. Nilai rata-rata FATO pada Perusahaan Sub Sektor Keramik, Porselen dan Kaca yang Terdaftar di Bursa Efek Indonesia tahun 2012-2016 sebesar 1,63 artinya setiap $\mathrm{Rp} 1$ total aset tetap dapat menghasilkan penjualan sebesar Rp 1,63.

Nilai FATO minimum sebesar 0,57 disebabkan oleh adanya penurunan penjualan yang lebih besar dibanding penurunan total aset tetap. Nilai FATO maksimum sebesar 3,42 dipengaruhi oleh terjadi peningkatan yang cukup besar pada penjualan tidak diimbangi dengan peningkatan total aset tetap.

\section{2) Gambaran Struktur Modal}

Long-term Debt to Equity Ratio (LtDER) sebagai berikut :

Tabel 3

LtDER Perusahaan Sub Sektor Keramik,

Porselen dan Kaca Periode 2012-2016

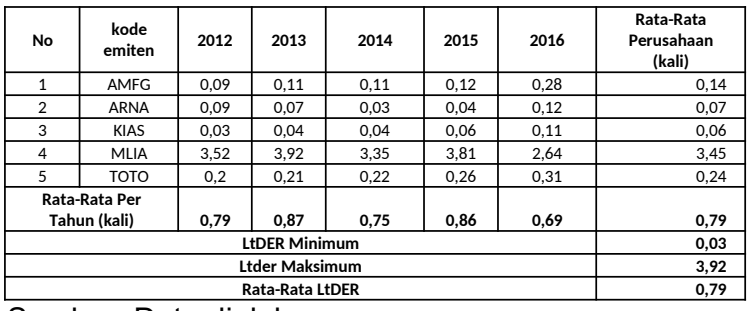

Sumber: Data diolah 
Berdasarkan Tabel 3 dapat disajikan grafik LtDER Perusahaan Sub Sektor Keramik, Porselen dan Kaca Periode 2012-2016 sebagai berikut:

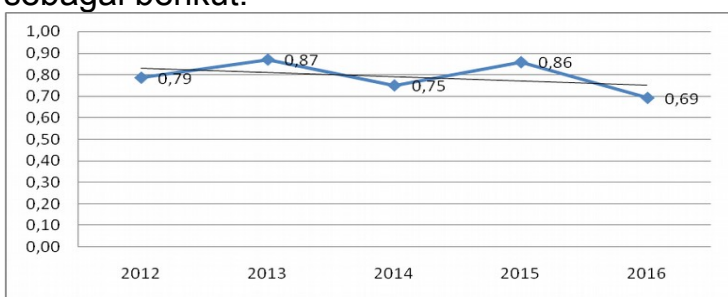

Sumber: Data Diolah (www.idx.co.id)

$$
\text { Gambar } 2
$$

Perkembangan LtDER Perusahaan Sub Sektor Keramik, Porselen dan Kaca yang Terdaftar di

\section{Bursa Efek Indonesia} Periode 2012-2016

Berdasarkan Tabel 3 dan Gambar 2, LtDER pada Perusahaan Sub Sektor Keramik, Porselen dan Kaca yang terdaftar di Bursa Efek Indonesia periode 2012-2016 berfluktuasi dan cenderung menurun. Nilai rata-rata LtDER sebesar 0,79 artinya setiap Rp 1 modal sendiri didanai oleh $\operatorname{Rp} 0,079$ hutang jangka panjang. Nilai LtDER minimum sebesar 0,03 disebabkan oleh penurunan hutang jangka panjang sedangkan pemakaian modal sendiri mengalami peningkatan.

Nilai LtDER maksimum sebesar 3,92 dipengaruhi oleh besarnya peningkatan utang jangka panjang sementara penggunaan modal sendiri lebih rendah.

\section{3) Gambaran Profitabilitas}

Return On Assets (ROA) Perusahaan Sub Sektor Keramik, Porselen dan Kaca sebagai berikut :

Tabel 4

ROA Perusahaan Sub Sektor Keramik, Porselen dan Kaca yang Terdaftar di Bursa Efek Indonesia

\begin{tabular}{|c|c|c|c|c|c|c|c|}
\hline \multicolumn{8}{|c|}{ Periode 2012-2016 } \\
\hline No & $\begin{array}{c}\text { kode } \\
\text { emiten }\end{array}$ & 2012 & 2013 & 2014 & 2015 & 2016 & $\begin{array}{l}\text { Rata-Rata } \\
\text { Perusahaaan } \\
\text { (kali) }\end{array}$ \\
\hline$\frac{1}{2}$ & $\begin{array}{ll}\text { AMFG } \\
\text { ARNA }\end{array}$ & 0,11 & 0,1 & 0,12 & 0,08 & 0,05 & 0,09 \\
\hline & $\frac{\text { ARIAA }}{\text { KIAS }}$ & 0,11 & 0,21 & 0,21 & 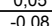 & $\frac{0,00}{-014}$ & 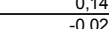 \\
\hline 4 & MLIA & $\frac{0,0}{0}$ & -0.0 & 0,0 & $-0,0$ & $\frac{1,14}{0}$ & $\frac{-0,04}{-0,01}$ \\
\hline 5 & TOTO & 0,15 & 0,14 & 0,14 & 0,12 & 0,07 & 0,12 \\
\hline \multicolumn{2}{|c|}{$\begin{array}{l}\text { Rata-Rata Per } \\
\text { Tabun (kali) }\end{array}$} & م & & 011 & 00 & م & \\
\hline \multirow{2}{*}{\multicolumn{7}{|c|}{$\begin{array}{l}\text { ROA Minimum } \\
\text { ROA Maksimum }\end{array}$}} & $\begin{array}{c}-0,06 \\
-0,14\end{array}$ \\
\hline & & & & & & & 0,21 \\
\hline
\end{tabular}

Sumber: Data diolah

Berdasarkan Tabel 4 di atas, maka disajikan grafik ROA sebagai berikut:

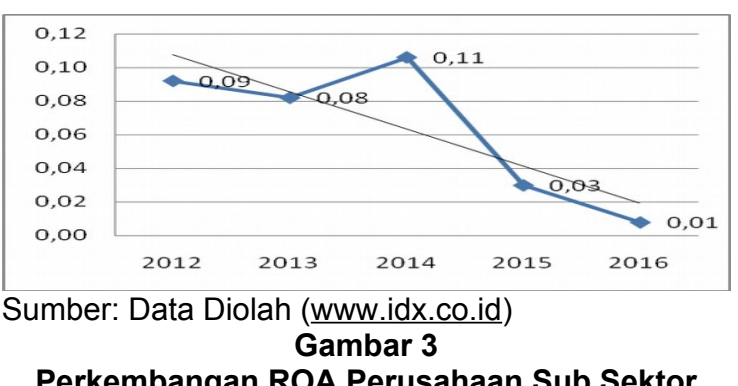

Perkembangan ROA Perusahaan Sub Sektor Keramik, Porselen dan Kaca yang Terdaftar di Bursa Efek Indonesia Periode 2012-2016
Berdasarkan Tabel 4 dan Gambar 3 tingkat ROA pada Perusahaan Sub Sektor Keramik, Porselen dan Kaca periode 20122016 berfluktuasi dan cenderung menurun. Nilai rata-rata $\mathrm{ROA}$ sebesar 0,06 artinya setiap Rp 1 aset dapat menghasilkan laba bersih setelah pajak sebesar Rp 0,06.

Nilai ROA minimum sebesar $-0,14$ disebabkan adanya penurunan drastis pada jumlah laba bersih setelah pajak dimana aset tetap stabil. Nilai ROA maksimum sebesar 0,21 dipengaruhi oleh peningkatan laba bersih setelah pajak yang drastis sedangkan total aset hanya terjadi sedikit peningkatan atau dengan kata lain kenaikan laba bersih setelah pajak tidak diimbangi dengan kenaikan total aset.

b. Analisis Deskrisptif Kuantitatif

1) Regresi Linier Berganda Tabel 5

Hasil Analisis Regresi Linier Berganda

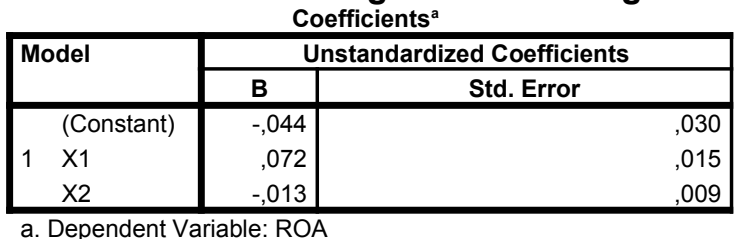

Sumber: Hasil Pengolahan Data

Berdasarkan Tabel 5, model persamaan regresi yang diperoleh sebagai berikut:

$$
\hat{\mathbf{Y}}=-0,044+0,072 \mathrm{X}_{1}-0,013 \mathrm{X}_{2}
$$

Berdasarkan model dapat diartikan bahwa manajemen aset berpengaruh positif sedangkan struktur modal berpengaruh negatif terhadap profitabilitas pada Perusahaan Sub Sektor Keramik, Porselen dan Kaca yang terdaftar di Bursa Efek Indonesia untuk periode 2012-2016.

2) Koefisien Korelasi dan Determinasi

Koefisien korelasi dan determinasi pada Tabel 6.

Tabel 6

Hasil Analisis Koefisien Korelasi dan Koefisien Determinasi

\begin{tabular}{|l|c|r|r|r|}
\hline Model & $\mathbf{R}$ & $\begin{array}{c}\mathbf{R} \\
\text { Square }\end{array}$ & $\begin{array}{c}\text { Adjusted } \\
\text { R Square }\end{array}$ & $\begin{array}{c}\text { Std. Error of } \\
\text { the Estimate }\end{array}$ \\
\hline 1 &, $\mathbf{7 8 8}^{\mathrm{a}}$ &, $\mathbf{6 2 2}$ &, 587 &, 05618 \\
\hline
\end{tabular}

Berdasarkan Tabel 6 nilai $r=0,788$ berarti hubungan antara manajemen aset dan struktur modal terhadap profitabilitas pada Perusahaan Sub Sektor Keramik, Porselen dan Kaca adalah kuat. Sementara koefisien determinasi $(\mathrm{R}$ Square $)=0,622$ berarti $62,2 \%$ return on assets dijelaskan oleh kedua variabel independen (fixed assets turnover ratio dan long-term debt to equity ratio), sedangkan sisanya dijelaskan oleh variabel lain seperti profit margin dan operating assets turnover.

3) Uji Hipotesis

a) Uji Simultan (Uji F) 
Hasil uji $\mathrm{F}$ dalam penelitian ini dapat dilihat pada Tabel 7 .

Tabel 7

Hasil Uji F

\begin{tabular}{|c|c|c|}
\hline Model & $F$ & Sig. \\
\hline $\begin{array}{ll} & \text { Regression } \\
1 & \begin{array}{l}\text { Residual } \\
\text { Total }\end{array} \\
\end{array}$ & 18,079 &, $000^{b}$ \\
\hline
\end{tabular}
$F_{\text {tabel }}(18,079>3,44)$ maka $H_{0}$ ditolak, berarti manajemen aset dan struktur modal berpengaruh signifikan terhadap profitabilitas pada Perusahaan Sub Sektor Keramik, Porselen dan Kaca yang terdaftar di Bursa Efek Indonesia.

b) Uji Parsial (Uji t)

Hasil uji t dalam penelitian ini dapat dilihat pada Tabel 8.

Tabel 8

Hasil Uji t

\begin{tabular}{|c|c|c|c|}
\hline \multirow[t]{2}{*}{ Model } & $\begin{array}{c}\text { Standardized } \\
\text { Coefficients }\end{array}$ & \multirow[t]{2}{*}{$\mathbf{t}$} & \multirow[t]{2}{*}{ Sig. } \\
\hline & Beta & & \\
\hline (Constant & & $-1,478$ & ,154 \\
\hline $\mathrm{X} 1$ & ,692 & 4,911 & ,000 \\
\hline $\mathrm{X} 2$ & ,200 & $-1,421$ & ,169 \\
\hline
\end{tabular}

Sumber: Hasil Pengolahan Data

Berdasarkan Tabel 8 untuk variabel manajemen aset, nilai $t_{\text {hitung }}>t_{\text {tabel }}(4,911>$ 2,073) atau tingkat signifikan 0,000 $<0,05$ maka $\mathrm{H}_{0}$ ditolak artinya manajemen aset berpengaruh signifikan terhadap profitabilitas pada Perusahaan Sub Sektor Keramik, Porselen dan Kaca yang terdaftar di Bursa Efek Indonesia.

Untuk struktur modal $t_{\text {hitung }}<t_{\text {tabel }}(-1,421<$ 2,073) atau tingkat signifikansi 1,296 > 0,05 maka $\mathrm{H}_{0}$ diterima artinya struktur modal berpengaruh tidak signifikan profitabilitas pada Perusahaan Sub Sektor Keramik, Porselen dan Kaca yang terdaftar di Bursa Efek Indonesia.

\section{Evaluasi}

a. Evaluasi Manajemen Aset pada Perusahaan Sub Sektor Keramik, Porselen dan Kaca

Berdasarkan hasil penelitian, perusahaan sebaiknya sebaiknya perusahaan tidak menambah terlalu banyak aset apabila aset tersebut tidak mendukung peningkatan penjualan karena aset yang terlalu besar justru akan menimbulkan biaya yang semakin besar juga, seperti biaya penyusutan maupun biaya pemeliharaan.

b. Evaluasi Struktur Modal pada Perusahaan Sub Sektor Keramik, Porselen dan Kaca
Berdasarkan penelitian ini, perusahaan sebaiknya perusahaan mengoptimalkan penggunaan utang dan perusahaan mencari kreditur yang memberikan tingkat suku bunga yang lebih rendah.

\section{b. Evaluasi}

Profitabilitas pada

Perusahaan Sub Sektor Keramik, Porselen dan Kaca

Berdasarkan hasil penelitian, perusahaan sebaiknya memaksimalkan aset tetap yang dimiliki perusahaan agar dapat menghasilkan penjualan lebih tinggi sehingga perputaran aset untuk menghasilkan penjualan semakin besar juga serta akan turut meningkatkan laba perusahaan. Juga sebaliknya tidak menambah terlalu banyak aset karena peningkatan aset yang terlalu besar akan meningkatkan biaya juga, seperti biaya penyusutan atau biaya pemeliharaan.

c. Evaluasi Pengaruh Manajemen Aset dan Struktur Modal Terhadap Profitabilitas pada Perusahaan Sub Sektor Keramik, Porselen dan Kaca

Berdasarkan hasil regresi linier berganda, maka model persamaan regresi adalah $\hat{Y}=$ $0,044+0,072 X_{1}-0,013 X_{2}$. Besar pengaruh yang di maksud menunjukkan manajemen aset $\left(X_{1}\right)$ sebesar 0,072 artinya setiap peningkatan satu satuan manajemen aset maka akan meningkatkan profitabilitas sebesar 0,072 dengan asumsi variabel independen lainnya dianggap tetap atau sama dengan nol. Hasil analisis regresi linier berganda tersebut mengindikasikan bahwa manajemen aset yang diukur dengan fixed assets turnover ratio berbanding lurus dengan profitabilitas. Artinya apabila fixed assets turnover ratio mengalami peningkatan maka akan meningkatkan profitabilitas. Hasil penelitian ini sejalan dengan pernyataan Sudana (2011:22) bahwa rasio perputaran aset tetap adalah mengukur efektivitas penggunaan aktiva tetap dalam menghasilkan penjualan bagi perusahaan.

Sedangkan besar pengaruh LtDER terhadap ROA sebesar 0,013, yang berarti bahwa setiap kenaikan LtDER sebesar satu satuan akan diikuti kenaikan Return On Assets (ROA) sebesar 0,013 dengan asumsi variabel independen lainnya dianggap tetap. Hasil analisis mengindikasikan bahwa struktur modal yang diukur dengan LtDER berbanding lurus dengan profitabilitas. Apabila LtDER mengalami peningkatan maka akan meningkatkan profitabilitas. Hasil penelitian ini tidak sejalan dengan pernyataan Sudana (2011:153), berdasarkan Signaling Theory (teori sinyal), perusahaan yang mampu menghasilkan laba cenderung meningkatkan jumlah hutangnya, karena tambahan pembayaran bunga akan dimbangi dengan laba sebelum pajak. Semakin sukses suatu 
perusahaan, kemungkinan akan menggunakan lebih banyak utang. Jadi dapat disimpulkan semakin tinggi rasio hutang terhadap total asat, maka semakin tinggi risiko keuangannya dimana risiko keuangan mempunyai hubungan positif dengan tingkat pengembalian sehingga jika semakin tinggi rasio ini, maka semakin besar tingkat pengembalian dan sebaliknya.

\section{KESIMPULAN DAN SARAN}

1. Kesimpulan

a. Nilai rata-rata FATO (fix assets turnover ratio) pada Perusahaan Sub Sektor Keramik, Porselen dan Kaca yang Terdaftar di Bursa Efek Indonesia tahun 2012-2016 sebesar 1,63.

b. Nilai rata-rata LtDER (long-term debt to equity ratio) pada Perusahaan Sub Sektor Keramik, Porselen dan Kaca yang Terdaftar di Bursa Efek Indonesia tahun 2012-2016 sebesar 0,79.

c. Nilai rata-rata ROA (return on assets) pada Perusahaan Sub Sektor Keramik, Porselen dan Kaca yang Terdaftar di Bursa Efek Indonesia tahun 2012-2016 sebesar 0,06.

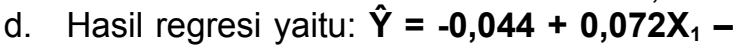
$\mathbf{0}, \mathbf{0 1 3 X}_{2}$. Artinya manajemen aset berpengaruh positif sedangkan struktur modal berpengaruh negatif terhadap profitabilitas pada Perusahaan Sub Sektor Keramik, Porselen dan Kaca yang Terdaftar di Bursa Efek Indonesia periode 2012-2016.

e. Koefisien korelasi dan determinasi diketahui bahwa nilai $r=0.788$ dimana terdapat hubungan yang sangat kuat antara return on assets dengan fixed assets turnover ratio dan long-term debt to equity ratio. Sementara koefisien determinasi $(\mathrm{R}$ Square $)=0,622$, artinya return on assets dapat dijelaskan oleh fixed assets turnover ratio dan long-term debt to equity ratio sebesar $62,2 \%$ dan sisanya dijelaskan oleh faktor lain diluar penelitian ini.

f. Uji $F$ diperoleh nillai $F_{\text {hitung }}>F_{\text {tabel }}(18,079>$ $3,44)$ atau dengan signifikasi $0,000<0,05$ maka $\mathrm{H}_{0}$ ditolak, artinya manajemen aset dan struktur modal berpengaruh signifikan terhadap profitabilitas pada Perusahaan Sub Sektor Keramik, Porselen dan Kaca yang Terdaftar di Bursa Efek Indonesia.

g. Uji $\mathrm{t}$ diperoleh nilai $\mathrm{t}_{\text {nitung }}>\mathrm{t}_{\text {tabel }}(4,911>$ 2,073 ) atau nilai signifikansi $0,000<0,05$ maka $\mathrm{H}_{0}$ ditolak artinya manajemen aset berpengaruh signifikan terhadap profitabilitas pada Perusahaan Sub Sektor Keramik, Porselen dan Kaca yang Terdaftar di Bursa Efek. Sedangkan untuk struktur modal $t_{\text {hitung }}<t_{\text {tabel }}(1,421<2,073)$ atau nilai signifikansi $0,169>0,05$ maka $\mathrm{H}_{0}$ diterima, artinya struktur modal berpengaruh tidak signifikan terhadap profitabilitas pada Perusahaan Sub Sektor Keramik, Porselen dan Kaca yang Terdaftar di Bursa Efek Indonesia.

2. Saran

a. Perusahaan sebaiknya tidak menambah terlalu banyak aset apabila aset tersebut tidak mendukung peningkatan penjualan karena aset yang terlalu besar justru akan menimbulkan biaya yang semakin besar juga, seperti biaya penyusutan dan biaya pemeliharaan.

b. Dalam hal ini sebaiknya perusahaan mengoptimalkan penggunaan utang dan perusahaan mencari kreditur yang memberikan tingkat suku bunga yang lebih rendah.

c. Sebaiknya perusahaan memaksimalkan penggunaan aset yang dimiliki perusahaan agar dapat menghasilkan penjualan yang lebih tinggi sehingga perputaran aset untuk menghasilkan penjualan semakin besar juga serta akan turut meningkatkan laba perusahaan.

\section{E. DAFTAR PUSTAKA}

Astuti, Dewi. 2004. Manajemen Keuangan Perusahaan. Jakarta: Ghalia Indonesia

Atmaja, Lukas Setia, 2003. Manajemen Keuangan. Edisi III. Yogayakarta: Andi. Baridwan, Zaki. 2004. Manajemen Keuangan Perusahaan. Jakarta: Ghalia Indonesia

Bursa Efek Indonesia. http://www.idx.co.id. tahun akses 2017.

Hery. 2009. Teori Akuntansi. Edisi I. Cetakan ke I. Jakarta: Prenada Media Group.

Horne, James C. Van dan John M. Wachowiccz, Jr. 2012. Prinsip-prinsip Manajemen Keuangan, Edisi Ketigabelas, Jilid Satu. Jakarta: Salemba Empat.

Kasmir. 2010. Pengantar Manajemen Keuangan. Edisi I. Cetakan II. Jakarta: Kencana Prenada Media Group.

Martani, Dwi, dkk. 2012. Akuntansi Keuangan Menengah Berbasis PSAK. Jakarta: Salemba Empat.

Sjahrial, Dermawan. 2009. Kumpulan Pembahasan Soal-soal Manajemen Keuangan. Edisi II. Jakarta: Mitra Wacana Media.

Sudana, I Made. 2011. Manajemen Keuangan Perusahaan Teori dan Praktik. Jakarta: Erlangga. 
